\title{
Effects of barley-bound organic selenium compared with inorganic selenite on selenium concentration and structure of tissues in pig
}

\author{
P. KURKELA and E. KÄÄNTEE \\ Food and Public Health Laboratory \\ SF-61800 KAUHAJOKI, Finland
}

\begin{abstract}
A study was made of the effects of barley feeds containing varying levels of natural grain selenium derived from fertilizer and of the effects of sodium selenite on selenium concentrations in the tissues of growing pigs and on the histological structure of myocardium and longissimus muscle.

The results indicated that organic grain selenium affects the selenium levels of porcine tissues significantly more than sodium selenite supplementation of the same amount. The organic selenium concentrations of feed and organs were found to be linearly correlated. Spleen, lung and heart were the most reliable indicators of tissue selenium level in pigs.

The selenium concentration of muscles of pigs fed on naturally seleniferous feed $(270 \mu \mathrm{g}$ $\mathrm{Se} / \mathrm{kg} \mathrm{DM})$ was at the internationally level $(500 \mu \mathrm{g} \mathrm{Se} / \mathrm{kg} \mathrm{DM}$ in meat), whereas the same amount of selenite in feed increased the selenium level of muscle only slightly (to $200 \mu \mathrm{g} \mathrm{Se} / \mathrm{kg}$ DM).

The histological structures of heart and muscle of pigs fed on naturally seleniferous feed were normal, whereas in the selenite group there were signs of muscle dystrophy when the selenium level was below $200 \mu \mathrm{g} \mathrm{Se} / \mathrm{kg} \mathrm{DM}$. In addition, the pigs given selenite were subsequently placed in a lower, fat-containing carcass class. Feed with a natural organic selenium level of $150-200 \mu \mathrm{g} \mathrm{Se} / \mathrm{kg} \mathrm{DM}$ is preferred to selenite selenium supplement in pork production.
\end{abstract}

\section{Introduction}

The low selenium content in Finnish fodder plants (OKSANEN and SANDHolm 1970, KURKELA 1982) makes it necessary to add selenium compounds to feeds during their production. Inorganic selenium supplements in feed have not always had the desired effect. Nutritional muscular dystrophy (NMD) has occurred even when the selenium content of the feed has been $0.1 \mathrm{mg} \mathrm{Se} / \mathrm{kg}$ DM.

Selenium-containing fertilizers can also be used to elevate the selenium content of feed. The changes in the selenium contents of 
animal tissues resulting from the use of these fertilizers for growing feed grain should be investigated and the effects of elevated tissue selenium contents examined from the point of foodstuffs hygiene.

The object of the present study was to investigate the effects of feed with varying levels of organic and inorganic selenium on

- health

- organ selenium content

- macroscopic and histological structure of the muscles in the pig.

\section{Materials and methods}

\section{Animals}

Twenty-five Yorkshire pigs with an initial weight of $25 \pm 0.5 \mathrm{~kg}$ were used in this study. They were divided into four groups (6 $+6+7+6)$. Each group received the test feed shown in Table 1 over a period of 110 days. In addition, samples for comparison were taken from the slaughterhouse from healthy pigs and from pigs with NMD.

\section{Feed and feeding}

Kemira Oy had grown barley with different selenium levels by fertilizing it one month after sowing with 0 to $1.0 \mathrm{~kg}$ sodium selenite per hectare (Korkman 1980). The feeds were mixtured from these barleys and protein mineral concentrate containing $40 \%$ raw protein and $18.5 \%$ minerals (Table 2) and from sodium selenite (Table 1). All the feeds used in the trial contained $30 \mathrm{IU} / \mathrm{kg}$ of vitamin E. All animals were given the group 1 feed for the four weeks leading up to the trial.
Table 2. Feed concentrate

\begin{tabular}{lc}
\hline Fish meal & $30 \%$ \\
Meat \& bone meal & 8 \\
Soya & 24 \\
Fodder yeast & 9 \\
Wheat bran & 5 \\
Pig vitamin & 3 \\
Ground chalk & 5 \\
Fodder phosphate & 4 \\
NaCl & 2.5 \\
Lignox & 4 \\
Molasses & 1 \\
\hline
\end{tabular}

$15 \%$ of this concentrate was mixed with barley in connection with grinding.

The pigs were kept in sties with concrete floors. They obtained test feed and water freely from automatic dispensers.

\section{Follow-up}

The animals were examined clinically once a week. They were slaughtered after 110 days. The carcasses were examined visually at the time the meat was inspected and classified in the slaughterhouse.

\section{Samples}

Blood and faeces samples were taken at the end of the trial. Samples of urine and bile were taken after slaughtering, together with tissue samples from the spleen, liver, muscle (dorsal longissimus muscle), lung, kidney, pancreas, brain, CNS, eye and coccyx. The tissue samples were taken by cutting a sagittal or otherwise representative sample from the organ or from one of its lobes. A sample

Table 1. Selenium concentrations of experimental feeds

\begin{tabular}{llc}
\hline $\begin{array}{l}\text { Trial } \\
\text { group }\end{array}$ & Feed (grain Se conc.) & $\begin{array}{c}\text { Total feed } \\
\text { Se concentration } \mu \mathrm{g} / \mathrm{kg} \mathrm{DM}\end{array}$ \\
\hline I & Barley $10 \mu \mathrm{g} / \mathrm{kg} \mathrm{DM}+15 \%$ feed concentrate & 100 \\
II & Barley $10 \mu \mathrm{g} / \mathrm{kg} \mathrm{DM}+15 \%$ feed concentrate $+\mathrm{Na}_{2} \mathrm{SeO}_{3}$ & 270 \\
III & Barley $180 \mu \mathrm{g} / \mathrm{kg} \mathrm{DM}+15 \%$ feed concentrate & 270 \\
IV & Barley $680 \mu \mathrm{g} / \mathrm{kg} \mathrm{DM}+15 \%$ feed concentrate & 700 \\
\hline
\end{tabular}


of myocardium was taken from the papillary muscle and the left ventricle wall.

Samples from equal-sized control pigs of the same strain from the same slaughterhouse used as random sample material were taken from the longissimus muscle and the myocardium both from clinically healthy animals and from those with nutritional muscular dystrophy (NMD).

The samples were frozen immediately and kept at $-20^{\circ} \mathrm{C}$ until analysed. Histological samples from the muscle, myocardium, liver and kidney were stored in $10 \%$ formalin.

\section{Chemical analysis and histological examination}

The method employed in the selenium determination was SAARI and PAASO's (1980) modification of the hydride method coupled with atomic absorption spectrophotometry. The lowest measurable selenium content by this method is $10 \mu \mathrm{g} \mathrm{Se} / \mathrm{kg}$.

\section{Statistical analysis}

The following methods were used in the statistical analysis of the results:

- The differences in tissue trace element contents between the feed groups were tested for homogeneity of variances by Bartlett's test, differences between means by one-way variance analysis and significantly different means were discriminated by Tukey's test.

- the dependence of tissue selenium level on feed selenium level was tested by linear regression analysis with feed selenium content as the systematic variable. Both the logarithmic function and the linear model were tested in the analysis.

- The correlations between the Se-levels of different organs were calculated using a correlation coefficient.

- Quality classification of the carcases and slaughtering weights were tested using Fischer's accurate four-field test, one-way variance analysis and Tukey's test.

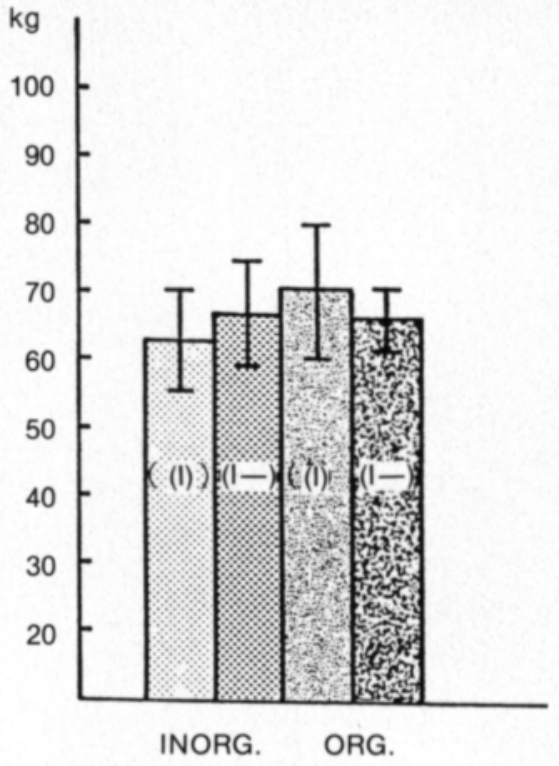

Fig. 1. Mean carcass weight and quality class

\section{Results}

The test pigs were clinically healthy during the tests. The mean slaughtering weights in the different groups are shown in Figure 1. No statistical differences were found in these.

In the quality classification, five pigs out of six in Group II were found to be fatty and were placed in class $\mathrm{I}-$. The rest of the pigs were classified as belonging to class I (Figure 1).

The mean selenium contents of samples taken from test animals are shown in Table 3.

It was found that sodium selenite supplement in the basic feed ( $270 \mu \mathrm{g} \mathrm{Se} / \mathrm{kg} \mathrm{DM})$ in Group II did not statistically significantly elevate the selenium content of the muscle and other organs, whereas a corresponding selenium supplement in organic form (Group III) resulted in a statistically significant increase. In the muscle this difference in the elevation of the selenium contents was about $250 \%$.

The change in the organ selenium contents in Groups I, II and IV was linear. The dependence of muscle selenium content on the level 


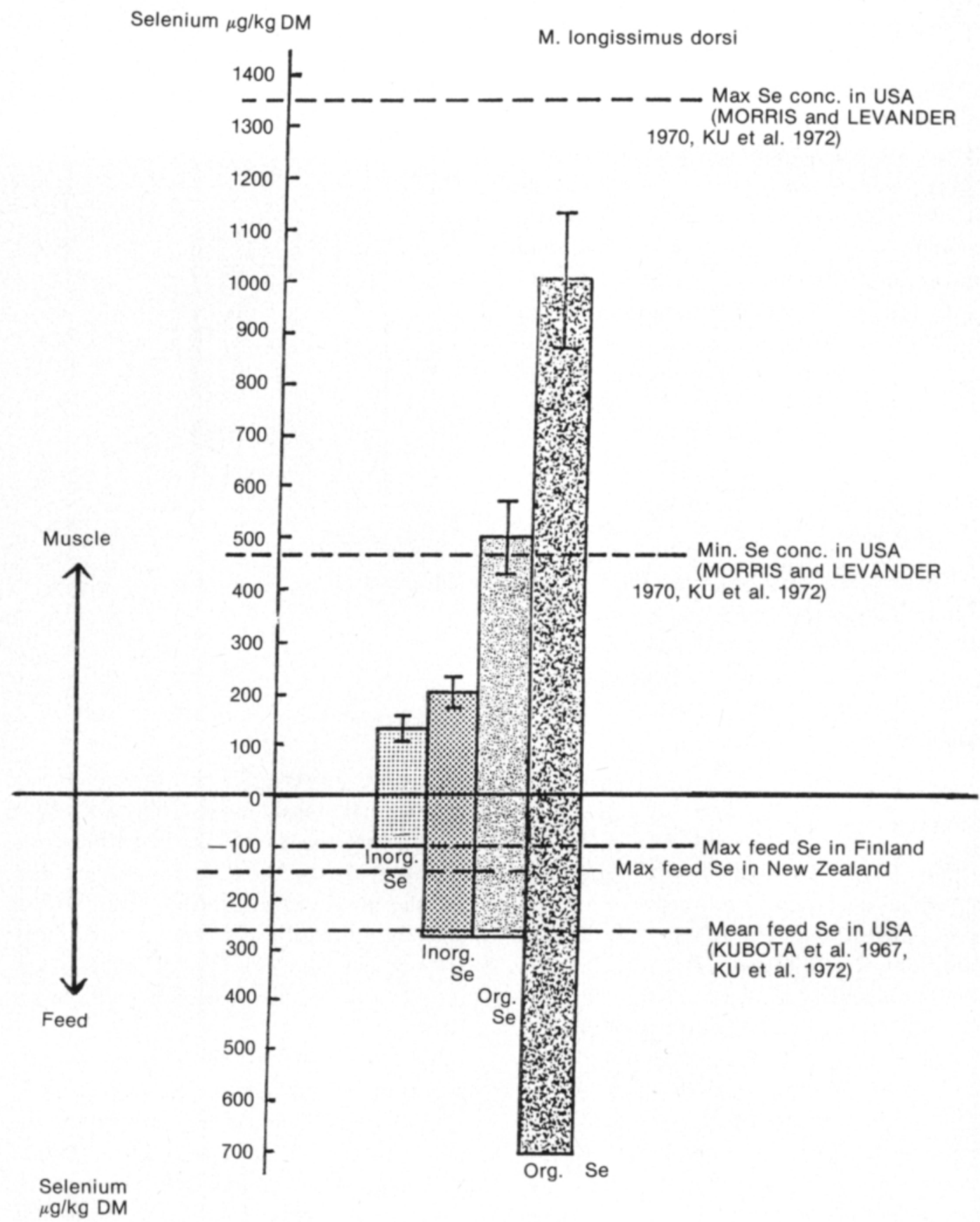

Fig. 2. Selenium content of muscle (M. longissimus dorsi) and associated selenium content in diet

of organic selenium in the feed is described by a curve of the second degree equation (Figure 3).

In the test groups, the selenium content of blood correlated best with the selenium con- tents of the myocardium, liver, CNS and bile $(0.998<\mathrm{r}<1)$. Blood selenium content was only indicative of the selenium content of muscle. The most reliable indicator organs of the body selenium content were found to be 
Table 3. Tissue selenium contents in test pigs $(\mu \mathrm{g} / \mathrm{kg}$ DM, mean \pm SD)

\begin{tabular}{lcccr}
\hline \multirow{2}{*}{$\begin{array}{l}\text { Trial group } \\
\text { Tissue }\end{array}$} & \multicolumn{4}{c}{ Trial } \\
\cline { 2 - 5 } & I & II & III & IV \\
\hline Blood & $550 \pm 64$ & $566 \pm 47$ & $614 \pm 63$ & $1341 \pm 929$ \\
Spleen & $1041 \pm 93$ & $1125 \pm 121$ & $1371 \pm 116$ & $2200 \pm 360$ \\
Bone & $141 \pm 34$ & $191 \pm 34$ & $414 \pm 115$ & $541 \pm 263$ \\
Muscle & $133 \pm 23$ & $200 \pm 28$ & $500 \pm 70$ & $1016 \pm 134$ \\
Heart & $683 \pm 23$ & $733 \pm 131$ & $1057 \pm 156$ & $2550 \pm 150$ \\
Liver & $1333 \pm 75$ & $1617 \pm 227$ & $1757 \pm 267$ & $3433 \pm 320$ \\
Lung & $691 \pm 53$ & $766 \pm 79$ & $950 \pm 96$ & $1716 \pm 60$ \\
Kidney & $5183 \pm 494$ & $5666 \pm 1020$ & $6128 \pm 832$ & $8550 \pm 495$ \\
Pancreas & & $975 \pm 25$ & $1325 \pm 375$ & \\
Brain & $400 \pm 68$ & $433 \pm 23$ & $707 \pm 86$ & $1450 \pm 150$ \\
Spinal cord & $136 \pm 19$ & $191 \pm 34$ & $228 \pm 52$ & $675 \pm 85$ \\
Eye & $233 \pm 23$ & $291 \pm 34$ & $457 \pm 72$ & $708 \pm 156$ \\
Bile, Combined sample & 100 & 100 & 150 & 450 \\
Urine, Combined sample & 150 & 2100 & 1300 & 4700 \\
Faeces, Combined sample & 500 & 1800 & 750 & 1700 \\
\hline
\end{tabular}

Selenium content of muscle $\mu \mathrm{g} / \mathrm{kg} \mathrm{DM}$

The minimum Se concentration of muscle $200 \mu \mathrm{g}$ Se/kg DM, without any histological signs of nutritional muscular dystrophy (NMD)

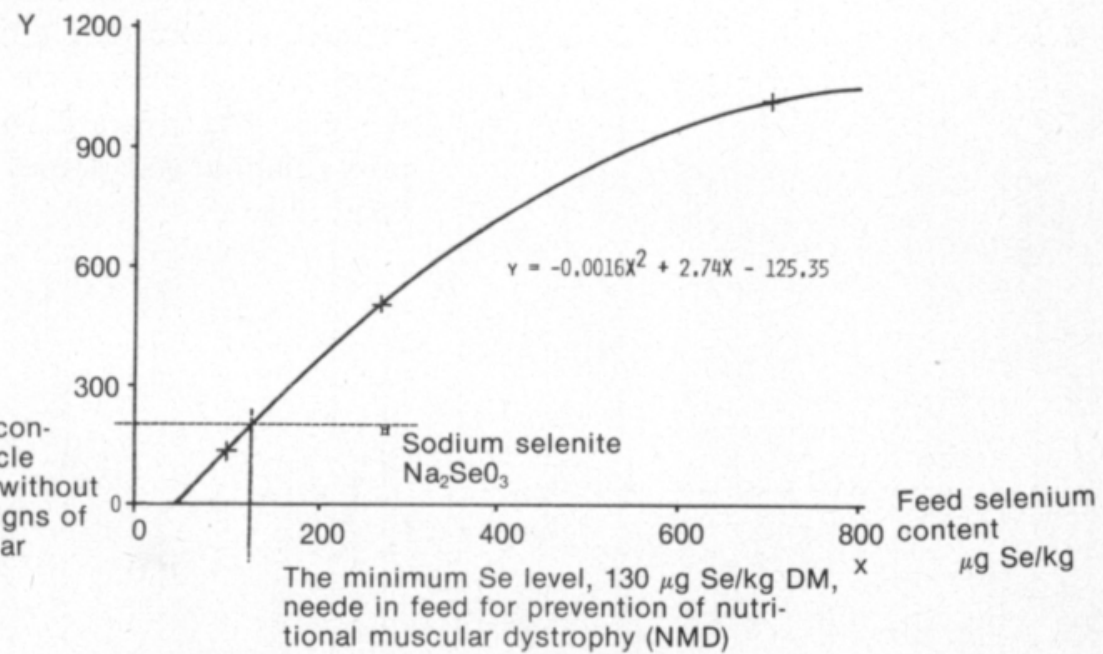

Fig. 3. Organic selenium in diet and associated selenium content of longissimus muscle of pig

the spleen and the lung, followed by the heart and the brain (Table 4).

The selenium content of the meat of clinically healthy pigs taken from the slaughterhouse and used as control samples was 150 $\mu \mathrm{g} \mathrm{Se} / \mathrm{kg} \mathrm{DM}$, and that of pigs with clinical signs of muscular dystrophy $378 \pm 79 \mu \mathrm{g}$ $\mathrm{Se} / \mathrm{kg} \mathrm{DM}$. The corresponding selenium contents of the myocardium in clinically healthy pigs were $600 \mu \mathrm{g} \mathrm{Se} / \mathrm{kg}$ DM and in pigs with 


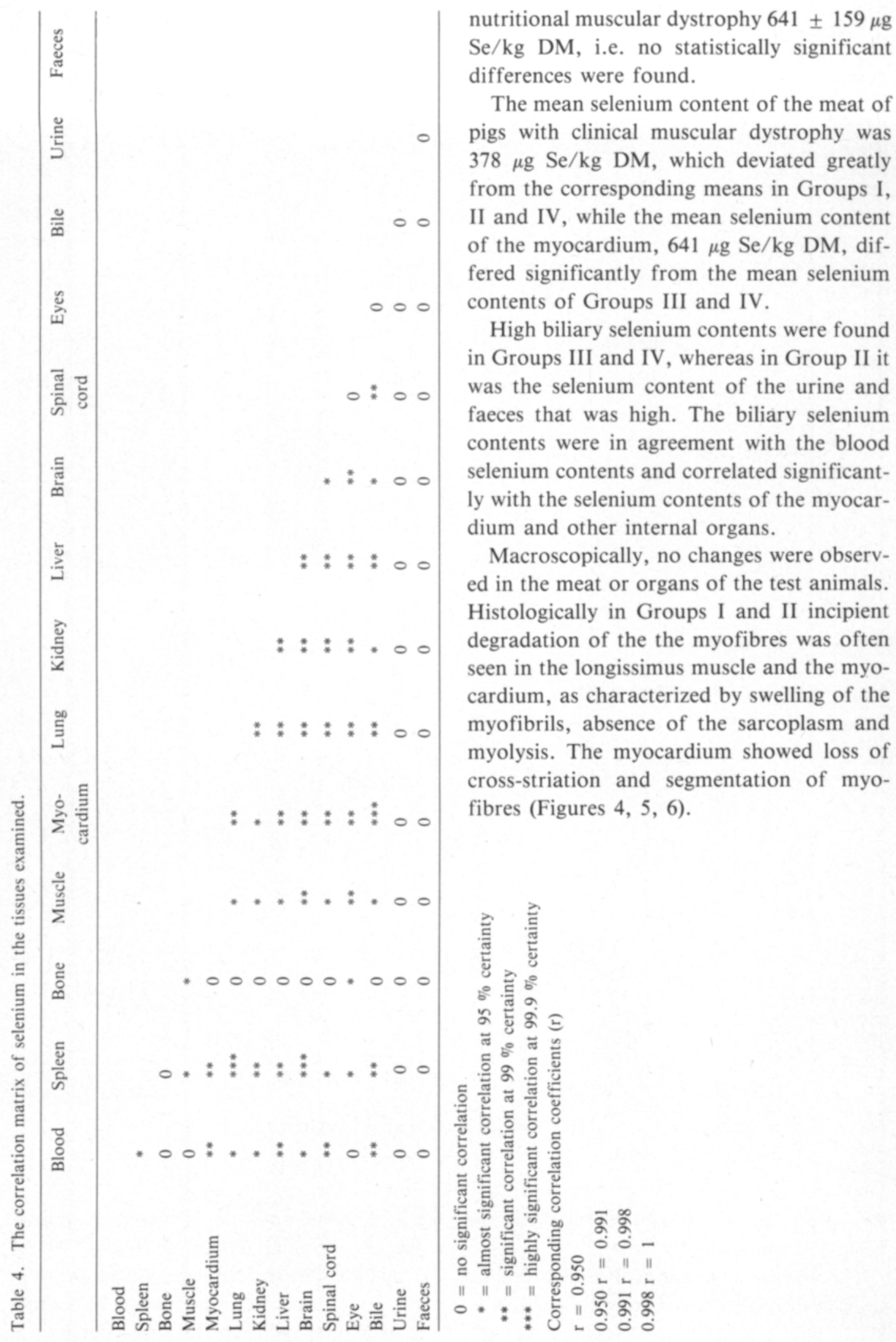




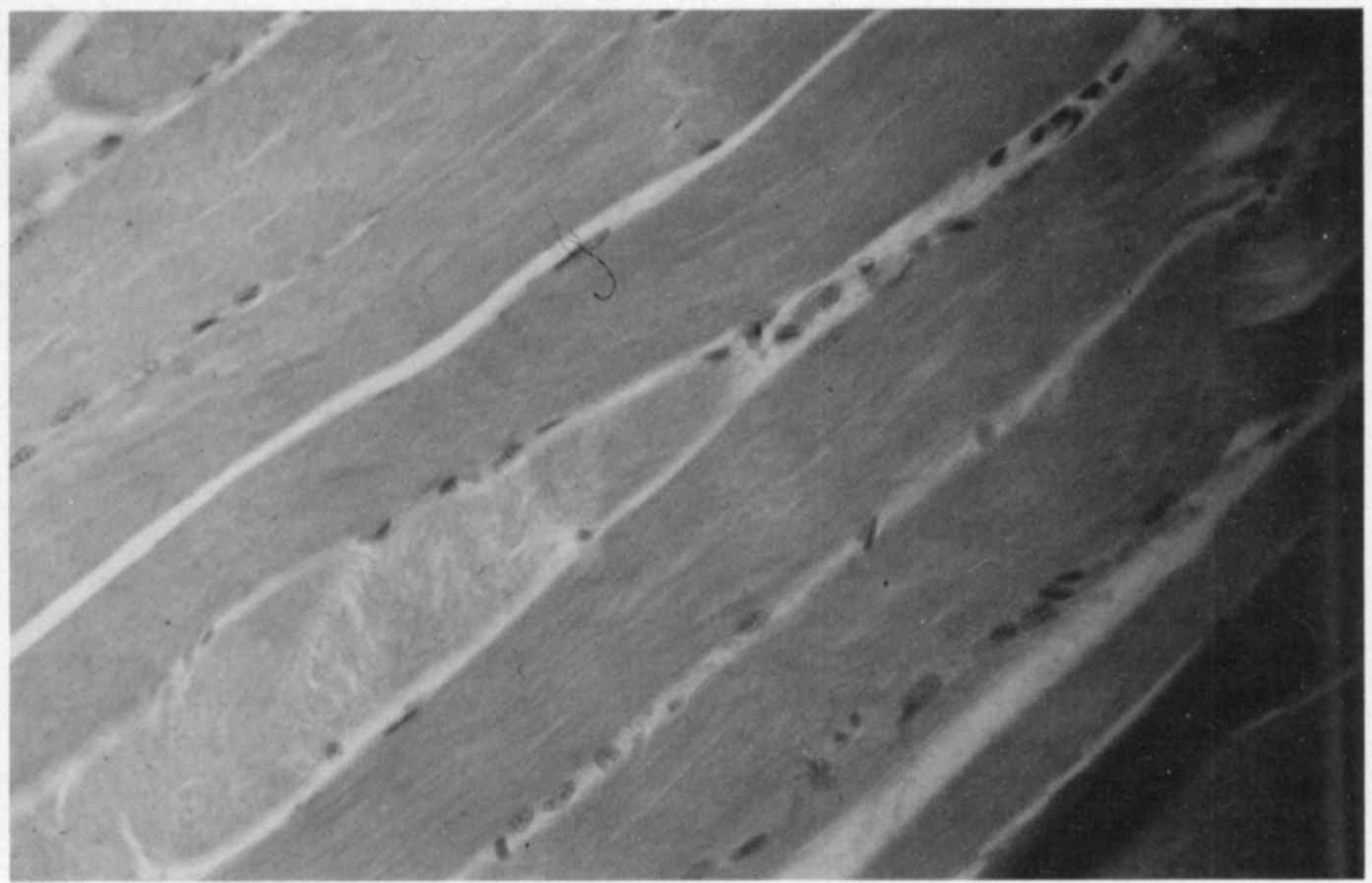

Fig. 4. Normal muscle, Se level over $200 \mu \mathrm{g} \mathrm{Se} / \mathrm{kg} \mathrm{Dm}$

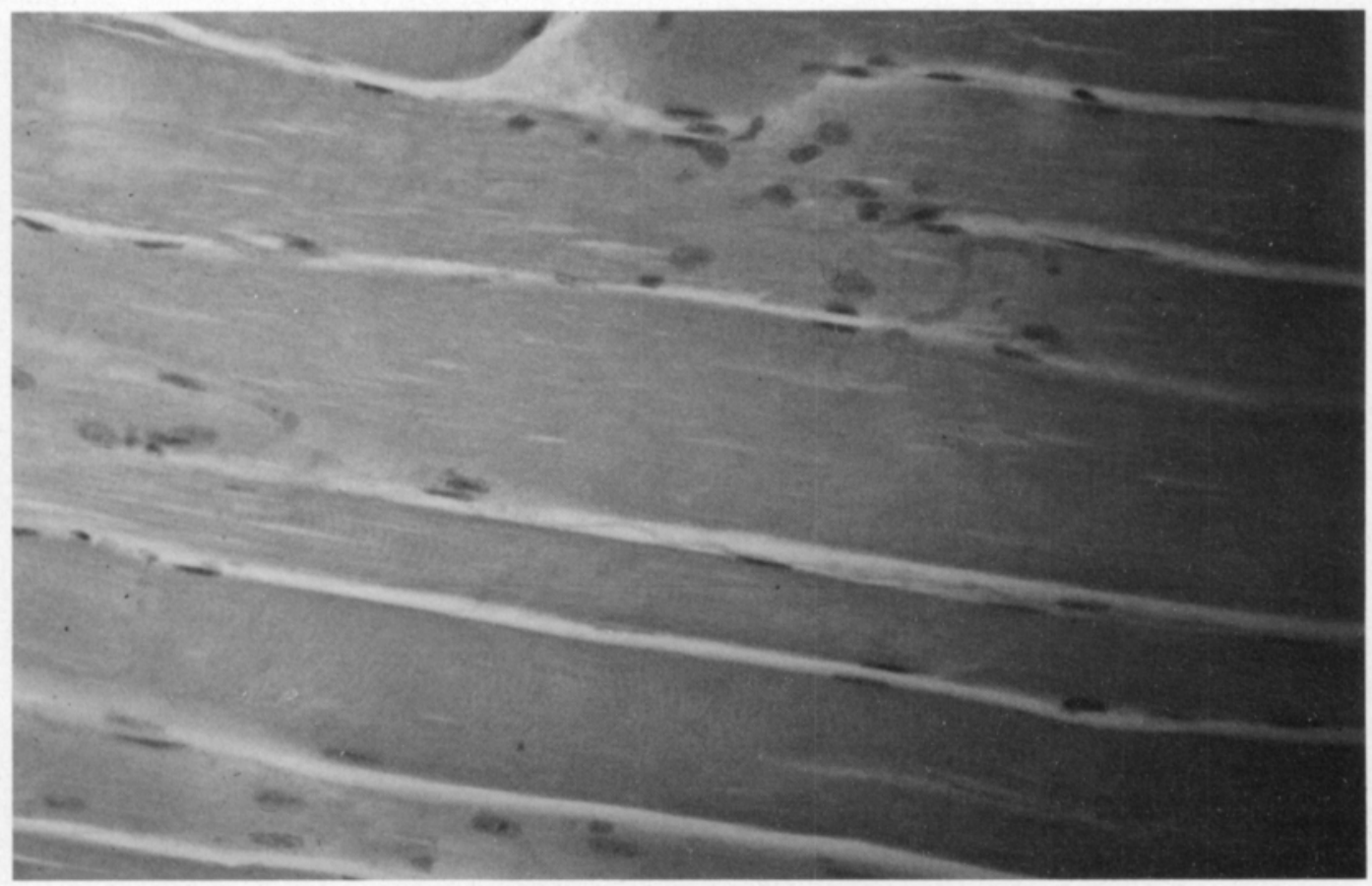

Fig. 5. Incipiẹnt muscular dystrophy (NMD), Se level $150-200 \mu \mathrm{g} / \mathrm{Se} / \mathrm{kg} \mathrm{DM}$ 


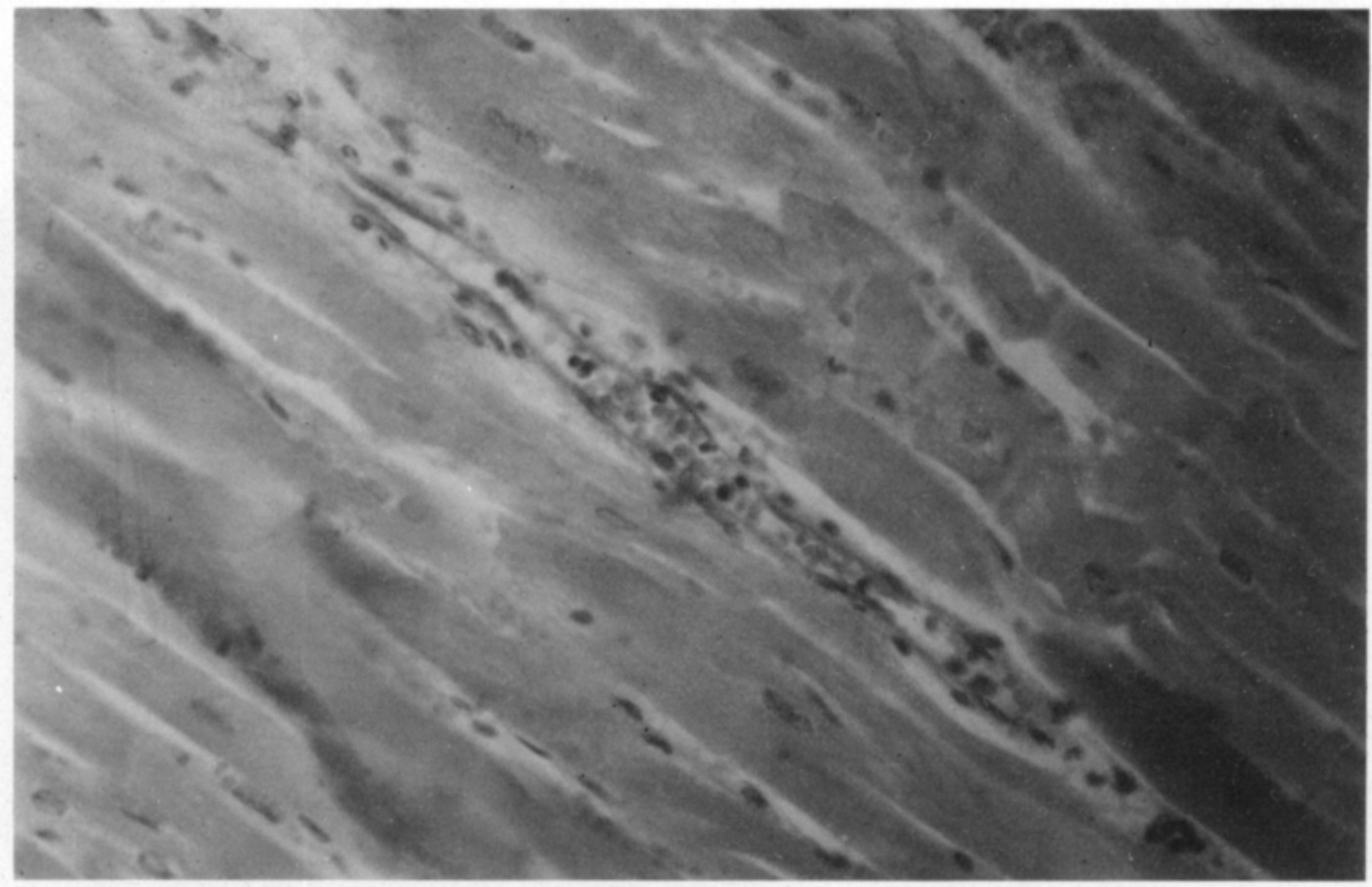

Fig. 6. Muscular dystrophy (NMD), Se level under $150 \mu \mathrm{g} \mathrm{Se} / \mathrm{kg} \mathrm{DM}$

Similar changes due to nutritional muscular dystrophy were also found in clinically healthy pigs in the control group. The samples from Groups III and IV did not show any histological changes.

These degenerative muscular and myocardial changes were manifested progressively with increasing severity when the muscular selenium content fell to $200-150 \mu \mathrm{g} \mathrm{Se} / \mathrm{kg}$ $\mathrm{DM}$ or below. In pigs with clinical nutritional muscular dystrophy, these histological changes were found in all samples of the longissimus muscle in which the selenium content was $200-450 \mu \mathrm{g} \mathrm{Se} / \mathrm{kg}$ DM.

Progressively increasing degradation changes were observed in the myocardium of the pigs in Groups I and II and of the clinically healthy control animals when the myocardium selenium content fell to $600-700 \mu \mathrm{g}$ $\mathrm{Se} / \mathrm{kg}$ DM or below. The selenium content of the myocardium of pigs with clinical nutritional muscular dystrophy was $600-850 \mu \mathrm{g}$ $\mathrm{Se} / \mathrm{kg}$ DM.

\section{Discussion}

The clinical condition of the test animals was good during the trial. The selenium contents used did not adversely affect the health of the pigs. This was as expected, because the selenium contents of the test feeds were clearly between the selenium contents causing deficiency states $(50 \mu \mathrm{g} \mathrm{Se} / \mathrm{kg} \mathrm{DM})$ reported by LATSHAw et al. (1977), and the content found to be toxic in pigs (5000) $\mu \mathrm{g} \mathrm{Se} / \mathrm{kg} \mathrm{DM}$ ). The selenium content of the feed given to Groups II and III, $270 \mu \mathrm{g} \mathrm{Se} / \mathrm{kg} \mathrm{DM}$, was of the same order as the mean natural selenium content of feed grain grown in the selenium-rich area of the USA (КивотA et al. 1967).

The different feeds used resulted in different selenium contents in the pig tissues. In Group I and in the healthy control group the selenium contents were $133 \pm 23 \mu \mathrm{g} \mathrm{Se} / \mathrm{kg}$ $\mathrm{DM}$ and $150 \mu \mathrm{g} \mathrm{Se} / \mathrm{kg} \mathrm{DM}$, corresponding to the selenium content of Finnish pork reported by NuUrtamo et al. (1980), which in turn is lower than the selenium contents of foreign 
pork, $450-1890 \mu \mathrm{g} \mathrm{Se} / \mathrm{kg}$ DM (LiNDBERG 1968, Morris and Levander 1970, Ku et al. 1972, NorRman 1977).

In Group II (feed containing $270 \mu \mathrm{g} \mathrm{Se} / \mathrm{kg}$ $\mathrm{DM}$ as sodium selenite) the selenium content of the pork was $200 \mu \mathrm{g} \mathrm{Se} / \mathrm{kg}$ DM. The elevation is small although the selenium content of the feed was three times greater than in Group I. In Group III, in which the feed contained the same amount of organic selenium of cereal origin, the selenium content of the muscle rose to $500 \mu \mathrm{g} \mathrm{Se} / \mathrm{kg} \mathrm{DM}$ and in Group IV to $1000 \mu \mathrm{g} \mathrm{Se} / \mathrm{kg}$ DM. The selenium level in the muscles was closely related to the organic dietary Se levels the pig received $(\mathrm{p}<0.001)$.

The differences could also be seen in tissue selenium determinations in different organs: the difference between the biological effect of sodium selenite and organic selenium of cereal origin is shown in the selenium contents of Groups II and III. The different chemical compounds of selenium, organic and inorganic, have different metabolic pathways in the organism (CARY et al. 1973). Selenomethionine and selenocysteine are biologically very active in pig (KU et al. 1972). In plants such as wheat and barley, most of the selenium is incorporated into protein as selenomethionine (OLson et al. 1970). In fish meal, selenium is known to be present as selenocysteine, the bioavailability of which has been found to be lower than that of selenomethionine.

Monogastric mammals cannot incorporate selenite selenium directly into cysteine or methionine, although the bacteria of intestinal tract, e.g. E. coli, can synthesize organoselenium compounds from selenite, which may explain the conversion of Se to nonlabile reduced forms in vivo (Allaway 1973).

The selenium bound in wheat or barley in the form of selenomethionine has a better bioavailability than the same quantity of selenium bound in meat or fish meal as selenocysteine (Ku et al. 1972). This is probably one reason for the low selenium content of Finnish pork, since the selenium content of
Finnish feed grain is low, 5-20 $\mu \mathrm{g} \mathrm{Se} / \mathrm{kg}$ $\mathrm{DM}$, and the pig feed mixtures used contain meat and fish meal as the source of protein. In the USA, soya is usually used instead of these (Ku et al. 1972).

It seemed that selenite selenium, selenomethionine and seleniferous plants (non accumulator species) may follow different metabolic pathways leading to differences in tissue concentrations of selenium, even though all these forms of Se are about equally effective in preventing selenium response diseases (CARY et al. 1973, JAAKKOla et al. 1982).

Variance analysis showed the selenium levels in the blood samples to be highly significantly dependent (p 80.001 ) on the feed selenium content, but in the regression analysis the dependence of blood selenium level on feed selenium content was only suggestive (90\%, regression coefficient 1.4 ). Contrary to the results obtained with chickens (KÄAnNTEE and Kurkela 1980), blood was not among the most reliable tissue indicators of body selenium content in the pig. The spleen, lungs, heart and brain were more reliable. The selenium contents of all these tissues rose quite high due to organic selenium in the feed.

In all test groups, the mean selenium contents of the organs were the highest in the kidneys, varying between 5200 and $8600 \mu \mathrm{g}$ $\mathrm{Se} / \mathrm{kg} \mathrm{DM}$; the next highest contents were in the liver, $1100-3500 \mu \mathrm{g} \mathrm{Se} / \mathrm{kg} \mathrm{DM}$, myocardium, 680-2550 $\mu \mathrm{g} \mathrm{Se} / \mathrm{kg} \mathrm{DM}$, spleen, $1000-2200 \mu \mathrm{g} \mathrm{Se} / \mathrm{kg} \mathrm{DM}$ and brain $400-$ $1450 \mu \mathrm{g} \mathrm{Se} / \mathrm{kg}$ DM. The lowest selenium content was found in the spinal cord, eye and bone. The greatest differences in the selenium contents between different test groups were found in the heart, liver, brain, spinal cord and bone.

The low selenium content of Finnish feeds is compensated during manufacture by the addition of sodium selenite, which has a low biological availability. This is shown by the incidence of histologically verified nutritional muscular dystrophy in Groups I and II, but also in healthy and unhealthy animals 
from the slaughterhouse. High selenium contents were found in both the muscle and myocardium of these unhealthy animals. This may be due either to the selenium administered to the animals in the form of medication or to mobilization of selenium from the body to the diseased areas (ToIKKA 1978).

The statistical results obtained indicate (Figure 3) that to produce histologically healthy pork with a selenium content of more than $200 \mu \mathrm{g} \mathrm{Se} / \mathrm{kg} \mathrm{DM}$, the content of organic selenium in the feed must be over 130 $\mu \mathrm{g} \mathrm{Se} / \mathrm{kg} \mathrm{DM}$.

Since neither the international selenium content of pork nor even the selenium level required for production of histopathologically healthy meat is obtained by the addition of sodium selenite, even up to $270 \mu \mathrm{g} \mathrm{Se} / \mathrm{kg}$ DM, the study supports the idea that the only way to elevate the selenium content of Finnish pork to the international standard is to raise the organic selenium content of pork feed to at least $150-200 \mu \mathrm{g} \mathrm{Se} / \mathrm{kg} \mathrm{DM}$ (i.e. $0.15-0.2 \mathrm{ppm})$. This can be done safely by fertilizing the feed grain by selenium-containing fertilizers or by foliar spraying with solutions containing selenium (KORKMAN 1980).

Considering the selenium levels in Table 2, and the average pork consumption of about 71 grammes per person per day in Finland (NuUrtamo et al. 1980) the range selenium per pig diet studied in the present investigation accounts for a difference of not more than $3-25 \mu \mathrm{g}$ selenium in the average daily intake in man. This $3-25 \mu \mathrm{g}$ is insignificant compared with the toxic level of $2400-3000$ $\mu \mathrm{g}$ selenium per day previously stated (NRC 1976), although it is of greater importance in terms of the proposed daily adequate amount of $50-200 \mu \mathrm{g}$ (NBH Circular No. 1762/1981). The toxic level could be exceeded with a daily consumption of more than about $1.1 \mathrm{~kg}$ pig kidney or more than about 2.1 to $2.6 \mathrm{~kg}$ liver, from pigs whose diet contains between 100 and $700 \mu \mathrm{g} \mathrm{Se} / \mathrm{kg} \mathrm{DM}$ (0.1-0.7 ppm).

\section{Summary}

An investigation was made into the effects of barley feeds with varying levels of natural organic selenium introduced by means of selenium-containing fertilizer and of inorganic sodium selenite on the concentrations of selenium in the tissues of growing pigs (blood, spleen, bone, muscle, heart, liver, lung, kidney, pancreas, brain, spinal cord and eye), and on the histological structure of myocardium and longissimus muscle.

The results indicated that natural organic grain selenium affects the selenium levels of tissues in pig significantly more (muscle $250 \%$ ) than sodium selenite supplementation of the same amount. The natural selenium concentrations of feed and organs were linearly correlated. Spleen, lung and heart were the most reliable indicators of tissue selenium levels in pigs.

When the feed selenium level was supplemented to $100 \mu \mathrm{g} \mathrm{Se} / \mathrm{kg} \mathrm{DM}(0.1 \mathrm{ppm})$ with sodium selenite, the selenium concentration of longissimus muscle was $133 \pm 23 \mu \mathrm{g} \mathrm{Se} / \mathrm{kg}$ DM. The selenium concentrations of muscles of pigs fed on naturally seleniferous feed, $270 \mu \mathrm{g} \mathrm{Se} / \mathrm{kg}$ DM were at the normal international level (500 $\mu \mathrm{g} \mathrm{Se} / \mathrm{kg} \mathrm{DM}$ in meat), whereas the same feed selenite selenium, 270 $\mu \mathrm{g} \mathrm{Se} / \mathrm{kg} \mathrm{DM}$, increased the selenium level of muscles only slightly (to $200 \mu \mathrm{g} \mathrm{Se} / \mathrm{kg} \mathrm{DM}$ ).

The histological structures of heart and striated muscles of the pigs fed on $270 \mu \mathrm{g}$ $\mathrm{Se} / \mathrm{kg} \mathrm{DM}$ organic selenium feed were normal and healthy, whereas in the group given the same amount of selenite there were histological signs of muscle dystrophy (NMD). A grain selenium concentration of $700 \mu \mathrm{g} \mathrm{Se} / \mathrm{kg}$ DM did not have any adverse effect on experimental animals.

In the quality classification of the carcasses, 5/6 pigs in the group receiving sodium selenite were placed in Class I- because of their high fat content.

The study supports the idea that natural organic selenium of grain origin of $150-$ 
$200 \mu \mathrm{g} \mathrm{Se} / \mathrm{kg} \mathrm{DM}(0.15-02 \mathrm{ppm})$ is the most suitable for pork production and more effective than selenite-induced selenium content both as regards the health of the animals and the elevation of the selenium content to the normal international level.

\section{References}

Allaway, W.H. 1973. Selenium in the food chain. Cornell Vet. 63, 151-170.

ANON 1976. National Research Council (NRC). Selenium and human health. Nutr. Rev. 43, 347-348.

Cary, E.E., Allaway, W.H. and Miller, M. 1973. Utilization of different forms of dietary selenium. J. Anim. Sci. 36, 285-292.

JaAkKola, K., Tummavuori, J., kurkela, P., Tolonen, M., Pirilä, A. and Arstila, A. 1982. Orgaanisen ja epăorgaanisen seleenin imeytyminen vereen terveillä suomalaisilla miehillă. (Absorption of organic and inorganic selenium in healthy Finnish men). Ympäristö ja Terveys, 5.

Korkman, J. 1980. The effect of selenium fertilizers on the selenium content of barley, spring wheat and potatoes. J. Sc. Agr. Soc. Finl. 52, 495-504.

Ku, P., Ely, W., Groce, A. and Ullrey, D. 1972. Natural dietary selenium, -tocopherol and effect on tissue selenium. J. of Anim. Sc. 34, 2, 208-211.

Kubota, J., Allaway, W., Carter, D., Cary, E. and LANZAR, V. 1967. Selenium in crops in United States in relation to selenium-responsive diseases of animals. J. Agr. Food. Chem. 15, 448.

Kurkela, P. 1982. Seleeni biologiassa ja lääketieteessã (Selenium in Biology and Medicine). Ympäristő ja Terveys 1, 3-36.

KAÁntee, E. and Kurkela, P. 1980. Comparative effects of barley feed and sodium selenite on selenium levels in hen eggs and tissues. J. Scient. Agric. Soc. Finl. 4, 357-367.
Latshaw, J., Ort, J. and Diesem, L. 1977. The selenium requirements of hen and effects of deficiency. Poult. Sci. 56, 1876-81.

LindBerG, P. 1968. Selenium determination in plant and animal material and in water. Acta Vet. Scand. Suppl. 23, 1-43.

Morris, V. and Levander, O. 1970. Selenium content of foods. J. Nutr. 100, 1383-1388.

Norrman, E. 1977. Selenbrist. Vår Näring 12, 6-7.

NuUrtamo, M., Varo, P., SaAri, E. and Koivistoinen, P. 1980. Mineral Elements Composition of Finnish Foods, V Meat and Meat Products. Acta Agr. Scand. Suppl. 22, 57-76.

Oksanen, H. and Sandholm, M. 1970. The selenium content of Finnish forage crops. J. Sci. Agr. Soc. Finl. 42, 251-254.

Olson, O.E., Novacek, E.J., Whitehead, E.J. and Pal. MER, I.S. 1970. Selenium in wheat. Phytochem. 9, $1181-1188$.

SAARI, E. and PaAso, A. 1980. Mineral Element Composition of Finnish Foods, II Analytical Methods. Acta Agr. Scand, Suppl. 22, 15-25.

TolKKA, M. 1978. Public Lecture at the University of Helsinki.

Ms received February 7, 1984 


\section{SELOSTUS}

\section{Ohran orgaanisen seleenin ja epäorgaanisen seleniitin vaikutuksista sian elimistön seleenipitoisuuksiin ja lihaksiston rakenteeseen.}

\section{P. Kurkela \& E. Kääntee}

\section{Kauhajoen elintarvikelaboratorio}

61800 Kauhajoki

Tutkimuksessa tarkastellaan ohran seleenin ja epäorgaanisen seleniitin vaikutuksia kasvavien sikojen elimistön seleenipitoisuuksiin sekă sydänlihaksen ja selkälihasten histologiseen rakenteeseen.

Tutkimuksiin käytettiin 25 sikaa jaettuna neljâăn ryhmăån sekă vertailuaineistona terveită ja lihasrappeumaa sairastavia teurassikoja teurastamosta. Koeryhmiä ruokittiin $110 \mathrm{vrk}$ :n ajan rehuilla joiden Se pitoisuudet olivat $100 \mu \mathrm{g}-700 \mu \mathrm{g} / \mathrm{kg}$.

Tulokset osoittivat että viljan orgaaninen seleeni kohotti porsaiden elimistön Se pitoisuutta huomattavasti enemmän kuin vastaava mäără natriumseleniittiă. Rehun seleenin ollessa viljaperäistä, $270 \mu \mathrm{g} / \mathrm{kg}$, kohosi lihan Se pitoisuus tasolle $500 \mu \mathrm{g} / \mathrm{kg}$ kuiva-ainetta, rehun seleenin ollessa natriumseleniittiä, $270 \mu \mathrm{g} / \mathrm{kg}$, oli lihan Se pitoisuus vain $200 \mu \mathrm{g} / \mathrm{kg}$ kuiva-ainetta.

Porsaan elimistön Se tason parhaat ja luotettavimmat indikaattorit olivat pernan keuhkojen ja sydämen Se pitoisuudet.

Histologisesti todettiin ohraseleeniă saaneiden porsaiden lihakset ja sydämet terveiksi, kun taas seleniittiporsailla lihasten Se pitoisuuden alittaessa $200 \mu \mathrm{g} / \mathrm{kg}$ kuiva-ainetta ilmeni lihasrappeumaa.

Tulokset osoittivat ohraan sidotun seleenin kohottavan elimistoon Se tasoa enemmăn kuin vastaavat mäărăt natriumseleniittiă ja suojaavan elimistöă paremmin lihasrappeumalta. 